\title{
Top court hears right-to-die appeal
}

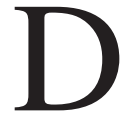
octors should have the final say in whether to help end the lives of patients with incurable or terminal conditions, Canada's top court heard in October.

"All doctors believe it is their professional and ethical duty to do no harm, which means that in most every case they will want to help their patients live, not die," said constitutional lawyer Joseph Arvay, who is representing several plaintiffs in Lee Carter et al. v. Attorney General of Canada et al., which challenges Canada's long-standing ban on assisted suicide. "We know physicians will be reluctant gatekeepers and only agree to it as a last resort."

The Supreme Court of Canada will have to decide whether the blanket prohibition on assisted suicide violates the charter rights of Canadians to life, liberty and security of the person, and equal treatment before the law.

Arvay said the law runs afoul of the constitution by condemning people with disabilities who are unable to end their lives without assistance to "horrific suffering, for some people akin to torture." This prompts some to take their lives prematurely while still ablebodied, rendering the effect of the law "completely inconsistent" with its objective to preserve life.
The law is further an affront to the dignity and autonomy of all Canadians, he said. "Right now we have the proverbial back alley where people have to buy these turkey bags that they fill with helium in order to die, or they have to order drugs from Thailand or Mexico, which if they don't work leave them brain-damaged and worse off."

The federal government countered that these issues were settled in 1993, when the Supreme Court refused Sue Rodriguez the right to a physicianassisted death on the grounds that an absolute ban was necessary to protect the vulnerable and uphold the sanctity of life. Of the nine justices present on Oct. 15, only Chief Justice Beverley McLachlin was present at the 1993 case; she voted in favour of physicianassisted death.

"Rodriguez is still good law," said Robert J. Frater, senior general counsel with the federal Department of Justice. Frater added that the European Court of Human Rights and high courts in the United States and United Kingdom similarly reject the idea that suicide or physician-assisted suicide is a matter of constitutional right.

Arvay and some interveners in the case, including certain religious and disability groups, argued that the govern-

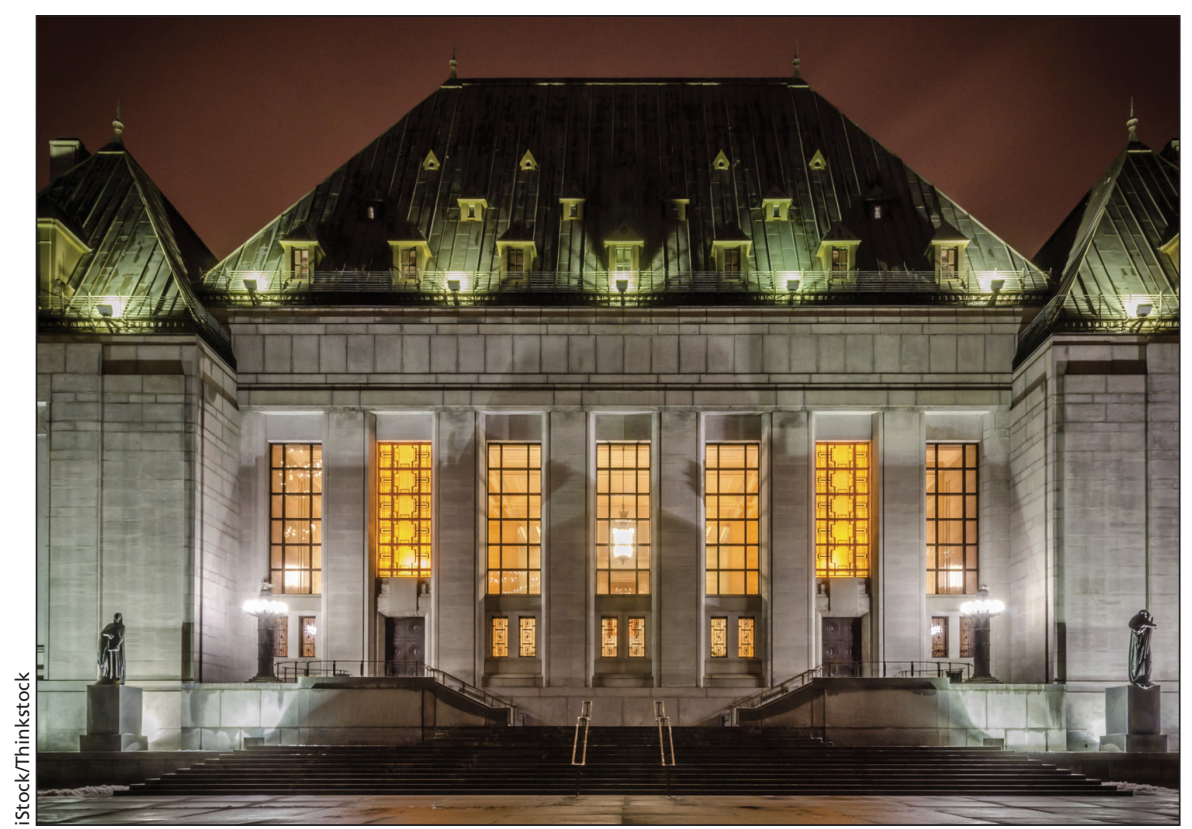

There won't be a rush for help to die should Canada strike down the ban on physicianassisted death, plaintiffs told the Supreme Court of Canada. ment's stance is too patronizing to people with disabilities, particularly in light of how much has changed since the Rodriguez case. The court now has the benefit of almost 15 years of experience with physician-assisted dying in other jurisdictions, said Arvay. He cited the finding of British Columbia's top court that the "risks inherent in permitting physician-assisted dying can be identified and substantially minimized through a carefully designed system," in which doctors are the gatekeepers.

"Although none of these systems are perfect, they're working well," said Arvay. It's unrealistic to advocate for zero risk, "because that's not how we operate the medical system," he added. "For all other end-of-life procedures [which may hasten death, such as palliative sedation or the decision to remove a ventilator] the risks are the same ... and we accept those risks."

The Canadian Medical Association (CMA), however, expressed "looming concern" about the ability of physicians to fill this role without additional protection.

CMA counsel Harry Underwood said that if the court strikes the ban on physician-assisted suicide, a "good faith attempt to comply with the legislative regime ought to be a complete bar to civil, criminal and disciplinary charges." In addition, doctors must be able to refuse to provide assistance in dying, "where they consider it inappropriate." CMA passed a resolution earlier this year affirming the physician's right to conscientious objection in the case of physician-assisted death.

Underwood noted several "real-world problems" that would complicate provision of physician-assisted dying, including the lack of access to palliative care and the fact that few physicians have the long-term relationships with their patients that are needed to assess a request for death.

"For doctors, whether a practice conforms to the law does not exhaust the question of whether they can support it," said Underwood.

The court's decision is not expected for several months. - Lauren Vogel, CMAJ

CMAJ 2014. DOI:10.1503/cmaj.109-4923 